BIBLIOGRAPHY.

(I). "Macfayden, A., Neucki, M., und Sieber, N. Untersuchungen über die chemischen Vorgänge in menschlichen Dünndarm." Centra1blatt für Bakteriologie und Parasitenkunde, so Band.

(2). Hoppe Seyler, Zur Kenntniss der Magengahrung mit besonderer Berucksichtigung der Magengase. Aleutsches Archiv. F. Klin. Medizin Bd., 1892 .

(3). J. Petruschky, Bakteriochemische Untersuchungen. Centralblatt für Bakteriologie, 7,1890 .

(4). "Boret, Des gaz produits par la fermentation anaerobieum" Annales de Micrographie, 2, 322 .

(5). Frankland, Percy F., Stanley, Arthur and Frew, W. Fermentations induced by the Pneumococcus of Friedlander. (Transactions of the Chemical Society of London, 1891 ).

(6). Cramer, E., Die Zusammensetzung der Bacterium in ihre Abhangigkeit von dem Nahrmaterial. (Arch. F, Hygiene, 1893).

(7). Ein Neuergasbilden der Bacillus ron Dr. F. Gartner. Centralblatt, Is Band.

(8.) Lander Brunton and Macfadyen. The fermentation of Bacteria. (Proceedings of the Royal Society of London, 46, 1889).

(9). The Fermentation Tube with special reference to Anaerobiosis and Gas-production among Bacteria, by Theobald Smith.

\title{
CHEMICAL VS. BACTERIOLOGICAL EXAMINATION OF POTABLE WATER.'
}

BY W. P. MASOX.

Received November 16, 1895 .

\begin{abstract}
$A$ PROPOS of the recent articles upon this question, which $A$ have appeared in the English papers, it is noteworthy that there is a growing tendency among physicians and civil engineers to belittle the chemists opinion regarding the potability of a water, and to pin their faith exclusively upon what the bacteriologist may have to say upon the subject. This feeling is strengthened by the publication of the results of such trials as that undertaken by the London Local Government Board, in which it will be remembered, water samples purposely inoculated with typhoid germs, were sent for analysis to one of England's leading chemists and were by him pronounced pure.

Those who set special value upon such a "test" of methods as the above, and who consider it quite final as showing the

1 Read before the New York Section.
\end{abstract}


inability of chemistry to detect pollution in a liquid which the bacteriologist would instantly pronounce very foul, should remember that such a sample of water could not be found in practice, and that the very conditions under which it was prepared, eliminated the chemical items indicating pollution, while it increased tremendously the signs governing the bacteriological side of the case.

The bacteriologist sought for the Eberth bacillus, and very naturally, quickly found it in a water purposely sown with a culture of the germ.

The chemist looked for those elements which always occur in sewage-laden water, whether the sewage be from sources of disease or otherwise, and, not finding them, he pronounced the water to be what it really was, free from sewage addition.

Sewage, as it occurs in practice, contains an immense deal of material other than that productive of disease, and it is upon just this comparatively harmless, but constantly present material that the chemist relies for the indication upon which he bases his opinions.

$\mathrm{He}$ is unable to say whether or not a sewage-laden water is disease-bearing on any particular date, for to him all sewage is alike, but he condemns the water, for the reason that, although it may be harmless to-day, it is impossible to predict what may be its condition to-morrow.

Within the week, I have been requested to make a bacteriological examination of the water of a certain well, in order to determine if it be affected by neighboring cesspools.

The physician who made the request was impressed with belief in the paramount value of such an examination and the comparative uselessness of chemical analysis.

I am quite convinced that, had I followed his suggestion, I should have sought in vain for any specific microbe, but inasmuch as upon chemical analysis, I found that the "chlorine" ran twenty-four parts per million, which is about ten times the local "normal," and the "nitric nitrogen" read nine parts per million in place of 0.116 , I condemned the water off hand without going further.

There is simply no comparison between the two methods in 
question for water problems of this class, and the value of chemistry is still more pronounced in those instances where it is possible to introduce common salt or lithium chloride into a source of suspected pollution, and then look for increased chlorine or presence of lithium in the water of the well. In legal cases touching upon this point of contamination of wells, by cemeteries for instance, the chemical testimony is especially strong.

In the matter of determining the suitability of a stream for city supply, the services of the bacteriologist should be unquestionably secured, but it is doubtful if his report can be considered of more importance than that of the chemist.

Chemical analysis, by comparing the water taken at the site of the proposed intake with that from the same stream above all points of possible pollution, can indicate whether or not up stream contamination is felt at the lower point; nor is it necessary that the polluting sewage be from pathogenic sources in order that its presence may be recognized.

As Dr. Dupré has pointed out, chemistry in such cases anticipates what may happen in the future, and, by timely advice, may prevent an outbreak of disease, while, on the other hand, the discovery of disease germs in a water is only possible after the water has become infected.

Bacteriology is of especial value, and greatly stperior to chemistry, for the testing of filters and watching any variation in their efficiency.

For this purpose the simple count of germs per cc. is most valuable, and differentiation is a secondary matter; for the assumption is a just one, that a filter which will remove the harmless bacteria, will take out the objectionable ones as well.

It is very far from my desire to decry the value of bacteriology, but I cannot but feel, that in their enthusiasm over the great triumphs of the new science, the people at large have gone slightly "bacteria mad," and are apt to expect more than can be furnished by the means and information now available.

Rensselaer Polytechnic Institute, Troy, N. Y. 